\title{
A New Single Cross Pop Corn Hybrid IHPC-1203 for Kharif Cultivation in North West Peninsular Zone, North East Peninsular Zone and Peninsular Zone
}

\author{
M. B. Patel", P. K. Parmar, K. H. Patel, S. K. Singh, H. S. Varma, \\ V. J. Patel and S. M. Khanorkar \\ Main Maize Research Station, Anand Agricultural University, \\ Godhra-389 001, Gujarat, India \\ *Corresponding author
}

Keywords

Pop corn, CLS, Chillopartellus, NEPZ, NWPZ, PZ, popping volume, popping $\%, \mathrm{ml} / \mathrm{cm}^{3}$

\section{Article Info}

Accepted:

15 August 2020

Available Online:

10 September 2020

\section{A B S T R A C T}

A new Single cross Pop corn hybrid IHPC-1203 was developed at Main Maize Research Station, AAU, Godhra, Gujarat and it was evaluated across the locations all over India during Kharif 2016 to Kharif 2018. This hybrid involves two diversified inbred parentsi.eIGPF-21 as female and IGPM-23 as male parent. It yielded on an average 38.76 Q/ha popcorn yield and found $24.8 \%$ superior in yield over the check VL Amber popcorn in the North West Peninsular Zone (NWPZ). It yielded on an average $32.94 \mathrm{Q} /$ ha popcorn yield and it is found $30.6 \%$ superior in yield over the check VL Amber popcorn in North East Peninsular Zone (NEPZ) and it yielded on an average 49.22 Q/ha popcorn yield and found $26.1 \%$ superior in yield over the check VL Amber popcorn in the Peninsular Zone (PZ). The quality point of view, this hybrid having high popping (92\%) and popping volume $(213 \mathrm{ml} / \mathrm{cm} 3)$ and it contains starch $75.55(\%), \beta$ - carotene $6.193(\mathrm{ppm})$ and tryptophan $0.104(\%)$. This hybrid shows degree of resistant to major diseases in artificial condition in all the zone. It exhibited moderate resistant against MLB and charcoal rot in NWPZ. Moderate resistance against C. Rot, P. rust and TLB diseases in PZ. Same way this hybrid exhibited varying degree of resistance to stem borer Chillopartellus in artificial condition. It exhibited moderate resistance against Chillopartellus in all three zone. Based on the overall performance and superiority over national check VL Amber Pop corn, it is identified and recommended to release for Kharif cultivation in the NEPZ, NWPZ and PZ in India.

\section{Introduction}

Maize is popularly known as "Corn" is most versatile emerging cash crops having wider adaptability under varied climatic condition. It is called queen of cereal globally. In India, maize is third most important cereal after wheat and rice. The maize is grown through out the year. Maize is being consumed both food and fodder crop and also required by various industries in India. In food category, specialties corn likes baby corn, sweet corn and popcorn are of great importance in value addition industries. Popcorn consumption 
may have boomed over the past decade, especially in multiplex cinemas, malls and food courts across metros and Tier-II cities as well as people conscious regarding health. Popcorn is popular and is consumed by people of all ages throughout the world (Park and Maga, 2001; Karababa, 2006; Ertas et al., 2009). The common health benefits of popcorn are such that it improves digestive health, is rich in antioxidants, helps in metabolism and provides energy, reduces depression, supports healthy bone function, controls blood sugar level, combats tumour cells, reduces craving for food and prevents aging. A popcorn kernel's small and strong hull contains the seed's hard, starchy endosperm with 14-20\% moisture, which turns to steam as the kernel is heated. Pressure from the steam continues to build until the hull ruptures, allowing the kernel to forcefully expand from 20 to 50 times its original size and finally call as popcorn. The quality of popcorn is expressed as popped volume, shape of the popped kernels, tenderness and flavor. The popped volume is perhaps most important because the commercial buyers buy on weight basis but sell the popped popcorn by volume.

Pop corn hybrid is not available in Gujarat till date. Thus the produce has less uniformity, which in turn affects their market acceptance, particularly in international market. In India, most of the hybrids available from private sector and some from public sector as well. Therefore, there is a need to develop popcorn hybrids for Gujarat and some part of country. Looking to the research reviews, Dofing et al., (2015) reported that there were significant differences among hybrid cultivars in popping volume, and that hybrid genotypes provided higher values than open-pollinated cultivars. In rabi, some of the farmers are growing only Amber popcorn variety (composite) resulted in low productivity. There is usually a negative relationship between the popping volume and overall seed yield. Higher popping volumes were recorded for low- or medium-yielding cultivars whereas highyielding cultivars had lower popping volumes (Pajic 2000). Consumers desire good popping popcorn with low numbers of unpopped kernels, and tender, palatable, delicious flakes having less seed coat remaining. On the other hand, growers look for high yielding capacity, plant stability, and good resistance to diseases and pests (Babic and Pajic 2012). Hence, there is a need to release medium maturity and high yielding popcorn hybrid to replace the composite/open pollinated varieties to enhance yield and productivity of popcorn. Therefore, this single cross popcorn hybrid IHPC-1203 was developed and tested in AICRP system across all over India and it was identified for release in three zones comprising the states of NWPZ (North West Plain Zone-Punjab, Haryana, Delhi, Uttarakhand, Uttar Pradesh), NEPZ (North East Plain Zone-Bihar, Jharkhand, Odisha, Uttar Pradesh (Eastern region), West Bengal) and PZ (Peninsular zone- Maharashtra, Karnataka, Andhra Pradesh, Tamil Nadu) because of its higher yield and good popping quality.

\section{Materials and Methods}

A new single cross Pop corn hybrid, IHPC1203 developed involving two inbred lines, IGPF-21 and IGPM-23 in rabi 2015-16 at Main Maize Research Station, Anand Agricultural University, Godhra, Gujarat. It is medium maturing yellow hybrid having orange flint grains. It matures within 85-90 days in Kharif season. The quality point of view, this hybrid contains $75.55 \%$ starch, $10.51 \%$ protein, $4.41 \%$ oil, and $6.193 \beta$ carotene. This hybrid was tested in AICRP system and in Kharif season trials were conducted at All Indian level across all the four zones comes under AICRP on maize network i.e. NWEZ, NEPZ, PZ and CWZ. 
The trials were conducted in Randomized Block Design with three replications by keeping $60 \times 20 \mathrm{~cm}$ sowing distance. The multilocation evaluation of hybrid carried out during Kharif -2016 to Kharif-2018. The randomized block design was used to conduct experiments by taking 6 rows of 4 meter length and $60 \times 20 \mathrm{~cm}$ plot size under Kharif conditions. All recommended agronomical cultivation practices for agro climatic zones were practiced to raise crop for observing traits. The standard methods laid by Indian Institute of Maize Research, Ludhiana were adapted to record observations and statistical analysis. Data on grain yield, days to tasselling, height of plant, grain moisture rate (content) in harvest, percentage of unpopped kernel and popping volume were measured for genotypes. Data were taken on tasselling time (days from planting to tasselling of $50 \%$ of plants), grain yield (kg ha-1), plant height $(\mathrm{cm})$, grain moisture in harvest $(\%)$, were estimated from a sample of all plants in two rows of every plot. Grain yield was corrected for a standard humidity of 14.5 and was transformed into $\mathrm{kg}$ ha-1 (Arnhold et al., 2009). After harvest, for each replication, genotypes samples were dried by natural convection at room temperature to $14 \%$ moisture. Among all the characters studied, three characters viz., moisture\%, final plant stand and cob yield per plot were taken. Standard statistical software RBDCovariance using these three characters was used get the final yield per hectare by ANCOVA (CD value, CV\% and SEM+ values).

Popping tests were performed by using a hot air popping machine (Arçelik, ARK77 MP, $230 \mathrm{~V}, 1200 \mathrm{~W})$. The moisture content of samples was $14 \pm 0.5 \%$ before popping. Before and after popping, the number of kernels for each sample was counted. Popped samples were poured into a $2000 \mathrm{~mL}$ plastic graduated cylinder, and volume recorded (Troyer, 2001;
Ceylan and Karababa, 2004; Gökmen, 2004; Sakin et al., 2005; Soylu and Tekkanat, 2007). The traits associated with expansion volume are the number of unpopped kernels and grain moisture content at the time of popping (Singh et al., 2007).

Expansion volume $=[$ Total popped volume $(\mathrm{cm} 3)]$ / [Original sample weight $(\mathrm{g})]$

Percentage of unpopped kernel $=($ Number of total unpopped kernels/Original number of kernels) X 100

Biochemical analysis of the hybrid was conducted at the Department of Biochemistry, B A College of Agriculture, Anand Agricultural University, Anand by using the standard protocol.

\section{Results and Discussion}

A new Single cross Pop corn hybrid IHPC1203 was evaluated across the locations all over India in four different zones comprising 23 states during Kharif 2016 to Kharif 2018. The yield performance of hybrid IHPC-1203 across the different zones are shown in the table 1. It shows that, the hybrid yielded on an average $38.76 \mathrm{Q} /$ ha popcorn yield and found $24.8 \%$ superior in yield over the national check, VL Amber popcorn in the North West Peninsular Zone (NWPZ). It yielded on an average $32.94 \mathrm{Q} / \mathrm{ha}$ popcorn yield and it is found $30.6 \%$ superior in yield over the national check, VL Amber popcorn in North East Peninsular Zone (NEPZ) and it yielded on an average $49.22 \mathrm{Q} /$ ha popcorn yield and found $26.1 \%$ superior in yield over the national check, VL Amber popcorn in the Peninsular Zone (PZ).As per the data presented in table 2 , the hybrid comes into silking 50.6 to 53.0 days across the zones in Kharif season which is preferable to farmers of the region as it takes 85-90 days to mature and harvest at proper stage. 
Table.1 Summary yield data of Coordinated Varietal Trials (Pop corn yield weight)

\begin{tabular}{|c|c|c|c|c|c|c|c|c|c|c|}
\hline \multicolumn{2}{|l|}{ Zones } & \multicolumn{3}{|c|}{ NWPZ } & \multicolumn{3}{|c|}{ NEPZ } & \multicolumn{3}{|c|}{$\mathbf{P Z}$} \\
\hline & $\begin{array}{l}\text { Year of } \\
\text { testing }\end{array}$ & $\begin{array}{l}\text { No. of trials/ } \\
\text { location }\end{array}$ & $\begin{array}{l}\text { IHPC- } \\
1203\end{array}$ & $\begin{array}{l}\text { VL Amber } \\
\text { popcorn }\end{array}$ & $\begin{array}{l}\text { No. of trials/ } \\
\text { location }\end{array}$ & $\begin{array}{l}\text { IHPC- } \\
1203\end{array}$ & $\begin{array}{l}\text { VL Amber } \\
\text { popcorn }\end{array}$ & $\begin{array}{l}\text { No. of trials/ } \\
\text { location }\end{array}$ & $\begin{array}{l}\text { IHPC- } \\
1203\end{array}$ & $\begin{array}{l}\text { VL Amber } \\
\text { popcorn }\end{array}$ \\
\hline \multirow{3}{*}{$\begin{array}{l}\text { Mean yield Q/ha) } \\
\text { Zonal } \\
\text { Across zones }\end{array}$} & Kharif-2016 & 25 & 41.03 & 31.04 & 25 & 36.97 & 24.82 & 25 & 46.87 & 30.82 \\
\hline & Kharif-2017 & 23 & 39.80 & 30.47 & 23 & 32.94 & 26.13 & 23 & 48.75 & 37.01 \\
\hline & Kharif-2018 & 25 & 35.44 & 31.66 & 25 & 28.92 & 24.74 & 25 & 52.03 & 49.24 \\
\hline \multicolumn{3}{|c|}{ Weighted Mean } & 38.76 & 31.06 & & 32.94 & 25.23 & & 49.22 & 39.02 \\
\hline \multirow{3}{*}{$\begin{array}{l}\text { Percentage increase or } \\
\text { decrease over the } \\
\text { checks and qualifying } \\
\text { varieties }\end{array}$} & Kharif-2016 & 25 & & 32.2 & 25 & & 49.0 & 25 & & 52.1 \\
\hline & Kharif-2017 & 23 & & 30.6 & 23 & & 26.0 & 23 & & 31.7 \\
\hline & Kharif-2018 & 25 & & 11.9 & 25 & & 16.9 & 25 & & 5.7 \\
\hline \multicolumn{3}{|c|}{ Weighted Mean } & & 24.8 & & & 30.6 & & & 26.12 \\
\hline \multicolumn{3}{|c|}{$\begin{array}{c}\text { Frequency in the top three group (pooled for three } \\
\text { years) }\end{array}$} & $2 / 3$ & $0 / 3$ & & $2 / 3$ & $0 / 3$ & & $2 / 3$ & $0 / 3$ \\
\hline
\end{tabular}

Table.2 Data on other important characters

\begin{tabular}{|c|c|c|c|c|c|c|c|}
\hline \multirow[t]{2}{*}{ Characters } & \multirow[t]{2}{*}{ Item } & \multicolumn{2}{|r|}{ NWPZ } & \multicolumn{2}{|r|}{ NEPZ } & \multicolumn{2}{|r|}{ PZ } \\
\hline & & IHPC-1203 & $\begin{array}{c}\text { National checks } 1 \\
\text { (VL Amber popcorn) }\end{array}$ & $\begin{array}{l}\text { IHPC- } \\
1203\end{array}$ & $\begin{array}{c}\text { National checks } 1 \\
\text { (VL Amber popcorn) }\end{array}$ & $\begin{array}{l}\text { IHPC- } \\
1203\end{array}$ & $\begin{array}{c}\text { National checks } 1 \\
\text { (VL Amber popcorn) }\end{array}$ \\
\hline \multirow[t]{3}{*}{ Plant height } & Kharif-2016 & 191 & 161 & 159 & 143 & 186 & 164 \\
\hline & Kharif-2017 & 199 & 167 & 164 & 145 & 189 & 175 \\
\hline & Kharif-2018 & 195 & 174 & 169 & 155 & 160 & 147 \\
\hline Average & & 195 & 167 & 164 & 148 & 178 & 162 \\
\hline \multirow[t]{3}{*}{ Ear height } & Kharif-2016 & 92 & 70 & 69 & 55 & 90 & 76 \\
\hline & Kharif-2017 & 106 & 93 & 76 & 68 & 96 & 87 \\
\hline & Kharif-2018 & 97 & 85 & 76 & 71 & 78 & 70 \\
\hline Average & & 98 & 83 & 74 & 65 & 88 & 78 \\
\hline \multirow{3}{*}{$\begin{array}{l}\text { Days to } 50 \quad \% \\
\text { silking }\end{array}$} & Kharif-2016 & 50 & 51 & 51 & 53 & 54 & 54 \\
\hline & Kharif-2017 & 51 & 51 & 50 & 52 & 52 & 53 \\
\hline & Kharif-2018 & 53 & 53 & 51 & 51 & 53 & 53 \\
\hline Average & & 51.3 & 51.7 & 50.6 & 52.0 & 53.0 & 53.3 \\
\hline
\end{tabular}


Table.3 Quality parameters of IGPHC-1202 (IHPC-1203) along with check

\begin{tabular}{|c|c|c|c|c|}
\hline \multirow[t]{2}{*}{ Year } & IHPC-1203 & Amber popcorn & IHPC-1203 & Amber popcorn \\
\hline & \multicolumn{2}{|c|}{ Popping $(\%)$} & \multicolumn{2}{|c|}{ Popping volume $\left(\mathrm{ml} / \mathrm{cm}^{3}\right)$} \\
\hline Rabi 2015-16 & 92 & 76 & 200 & 130 \\
\hline Rabi 2016-17 & 96 & 90 & 250 & 200 \\
\hline Rabi 2017-18 & 89 & 80 & 190 & 170 \\
\hline Average & 92 & 82 & 213 & 167 \\
\hline
\end{tabular}

Table.4 Biochemical status in seed of propose hybrid and check

\begin{tabular}{|l|c|c|l|c|c|}
\hline \multicolumn{1}{|c|}{ Traits } & $\begin{array}{c}\text { IHPC- } \\
\mathbf{1 2 0 3}\end{array}$ & $\begin{array}{c}\text { Amber } \\
\text { Popcorn }\end{array}$ & \multicolumn{1}{|c|}{ Traits } & IHPC-1203 & $\begin{array}{c}\text { Amber } \\
\text { Popcorn }\end{array}$ \\
\hline Moisture (\%) & 6.05 & 4.73 & Flavanoid (\%) & 0.094 & 0.098 \\
\hline Starch (\%) & 75.55 & 70.86 & Lysine (\%) & 0.293 & 0.299 \\
\hline Sugar (\%) & 2.511 & 3.304 & Tryptophan (\%) & 0.104 & 0.091 \\
\hline Reducing Sugar (\%) & 0.101 & 0.176 & Fiber (\%) & 2.619 & 2.778 \\
\hline Phenol (\%) & 0.152 & 0.166 & $\beta$ Carotene (ppm) & 6.193 & 8.022 \\
\hline
\end{tabular}

Table.5a Reaction to major diseases (NWPZ)

\begin{tabular}{|c|c|c|c|c|}
\hline \multicolumn{5}{|c|}{ Name of proposed hybrid : IHPC-1203 (Godhra Hybrid Popcorn-1203) } \\
\hline Disease Name & $\begin{array}{l}\text { Condition of } \\
\text { screening }\end{array}$ & Season & IHPC-1203 & $\begin{array}{l}\text { National checks } 1 \\
\text { (VL Amber popcorn) }\end{array}$ \\
\hline \multirow[t]{6}{*}{ MLB } & Natural & Kharif-2016 & - & - \\
\hline & & Kharif-2017 & - & - \\
\hline & & Kharif-2018 & - & - \\
\hline & Artificial & Kharif-2016 & MR & MR \\
\hline & & Kharif-2017 & MS & MS \\
\hline & & Kharif-2018 & MS & MS \\
\hline \multirow[t]{6}{*}{ Charcol rot } & Natural & Kharif-2016 & - & - \\
\hline & & Kharif-2017 & - & - \\
\hline & & Kharif-2018 & - & - \\
\hline & Artificial & Kharif-2016 & MR & S \\
\hline & & Kharif-2017 & MR & MS \\
\hline & & Kharif-2018 & MS & $\mathrm{S}$ \\
\hline \multirow[t]{6}{*}{ BLSB } & Natural & Kharif-2016 & - & - \\
\hline & & Kharif-2017 & - & - \\
\hline & & Kharif-2018 & - & - \\
\hline & Artificial & Kharif-2016 & $S$ & S \\
\hline & & Kharif-2017 & MS & MS \\
\hline & & Kharif-2018 & MS & MS \\
\hline \multirow[t]{6}{*}{ TLB } & Natural & Kharif-2016 & - & - \\
\hline & & Kharif-2017 & - & - \\
\hline & & Kharif-2018 & - & - \\
\hline & Artificial & Kharif-2016 & - & - \\
\hline & & Kharif-2017 & - & - \\
\hline & & Kharif-2018 & - & - \\
\hline
\end{tabular}


Table.5b Reaction to major diseases (NEPZ)

\begin{tabular}{|c|c|c|c|c|}
\hline Disease Name & $\begin{array}{l}\text { Condition of } \\
\text { screening }\end{array}$ & Season & IHPC-1203 & $\begin{array}{l}\text { National checks } 1 \\
\text { (VL Amber popcorn) }\end{array}$ \\
\hline \multirow[t]{6}{*}{ MLB } & Natural & Kharif-2016 & - & - \\
\hline & & Kharif-2017 & - & - \\
\hline & & Kharif-2018 & - & - \\
\hline & Artificial & Kharif-2016 & - & - \\
\hline & & Kharif-2017 & MS & S \\
\hline & & Kharif-2018 & MS & MS \\
\hline \multirow[t]{6}{*}{ CLS } & Natural & Kharif-2016 & - & - \\
\hline & & Kharif-2017 & - & - \\
\hline & & Kharif-2018 & - & - \\
\hline & Artificial & Kharif-2016 & - & - \\
\hline & & Kharif-2017 & - & - \\
\hline & & Kharif-2018 & - & - \\
\hline \multirow[t]{6}{*}{ BLSB } & Natural & Kharif-2016 & - & - \\
\hline & & Kharif-2017 & - & - \\
\hline & & Kharif-2018 & - & - \\
\hline & Artificial & Kharif-2016 & - & - \\
\hline & & Kharif-2017 & - & - \\
\hline & & Kharif-2018 & - & - \\
\hline \multirow[t]{6}{*}{ TLB } & Natural & Kharif-2016 & - & - \\
\hline & & Kharif-2017 & - & - \\
\hline & & Kharif-2018 & - & - \\
\hline & Artificial & Kharif-2016 & $\mathrm{S}$ & $\mathrm{S}$ \\
\hline & & Kharif-2017 & MS & MS \\
\hline & & Kharif-2018 & - & - \\
\hline
\end{tabular}

Table.5c Reaction to major diseases (PZ)

\begin{tabular}{|c|c|c|c|c|}
\hline Disease Name & $\begin{array}{c}\text { Condition of } \\
\text { screening }\end{array}$ & Season & IHPC-1203 & $\begin{array}{c}\text { National checks } 1 \\
\text { (VL Amber popcorn) }\end{array}$ \\
\hline \multirow[t]{6}{*}{ P.rust } & Natural & Kharif-2016 & - & - \\
\hline & & Kharif-2017 & - & - \\
\hline & & Kharif-2018 & - & - \\
\hline & Artificial & Kharif-2016 & - & - \\
\hline & & Kharif-2017 & - & - \\
\hline & & Kharif-2018 & MR & MR \\
\hline \multirow[t]{6}{*}{ C.ROT } & Natural & Kharif-2016 & - & - \\
\hline & & Kharif-2017 & - & - \\
\hline & & Kharif-2018 & - & - \\
\hline & Artificial & Kharif-2016 & MR & S \\
\hline & & Kharif-2017 & MR & MS \\
\hline & & Kharif-2018 & - & - \\
\hline \multirow[t]{6}{*}{ TLB } & Natural & Kharif-2016 & - & - \\
\hline & & Kharif-2017 & - & - \\
\hline & & Kharif-2018 & - & - \\
\hline & Artificial & Kharif-2016 & S & S \\
\hline & & Kharif-2017 & - & - \\
\hline & & Kharif-2018 & MR & MS \\
\hline
\end{tabular}


Table.6 Reaction to Insects-Pests

\begin{tabular}{|c|c|c|c|c|c|c|c|c|}
\hline \multirow[b]{2}{*}{$\begin{array}{l}\text { Insect } \\
\text { Name }\end{array}$} & & \multirow[b]{2}{*}{ Item } & \multicolumn{2}{|c|}{ NWPZ } & \multicolumn{2}{|c|}{ NEPZ } & \multicolumn{2}{|r|}{ PZ } \\
\hline & & & $\begin{array}{l}\text { IHPC- } \\
1203\end{array}$ & $\begin{array}{l}\text { National } \\
\text { checks } 1 \\
\text { (VL Amber } \\
\text { popcorn) }\end{array}$ & $\begin{array}{l}\text { IHPC- } \\
1203\end{array}$ & $\begin{array}{l}\text { National } \\
\text { checks } 1 \\
\text { (VL Amber } \\
\text { popcorn) }\end{array}$ & $\begin{array}{l}\text { IHPC } \\
-1203\end{array}$ & $\begin{array}{l}\text { National } \\
\text { checks } 1 \\
\text { (VL Amber } \\
\text { popcorn) }\end{array}$ \\
\hline \multirow[t]{3}{*}{$\begin{array}{l}\text { ChilloPart } \\
\text { ellus }\end{array}$} & Natural & $\begin{array}{l}\text { Kharif- } \\
2016\end{array}$ & $\mathrm{R}$ & $\mathrm{R}$ & $\mathrm{R}$ & MR & $\mathrm{R}$ & MR \\
\hline & & $\begin{array}{l}\text { Kharif- } \\
2017\end{array}$ & MR & MR & MR & $\mathrm{S}$ & $S$ & MR \\
\hline & & $\begin{array}{l}\text { Kharif- } \\
2018\end{array}$ & MR & MR & MR & MR & MR & $S$ \\
\hline
\end{tabular}

Scale:1-1.9: Highly Resistant ,2.0-3.0: Resistant, 3.1-5.0 : Moderate Resistant, 5.1-7.0: Susceptible, >7.1 : Highly Susceptible

R : Resistant, MR: Moderate resistant, S: Susceptible, MS: Moderate Susceptible

In addition of grain yield, popping $\%$ and popping volume is the most important factor for the daily use, table and industrial purpose. Looking to the analysis and data in table 3 , this hybrid is expressing high popping (92\%) and popping volume $(213 \mathrm{~cm} 3)$ which is higher than amber popcorn. In context to its biochemical features and the data showed in table 4 , the small sized orange flint grain exhibited good quality of nutritive factors like $75.55 \%$ starch, $10.51 \%$ protein, 4.41 oil and $6.19 \mathrm{ppm} \beta$ - carotene in seed. Yield and quality of pop corn may varied from variety to variety was observed by Mehmet Ali Sakin et al., (2005) while studying the effect of pop corn cultivars. The nutritional composition of popcorn may vary with varieties, the environment and the manner in which it is prepared. However this has not been reported in the literature. The nutrients reported in Nigerian popcorn hybrids include 64\% carbohydrate, $8.7 \%$ protein and $8.8 \%$ fat (Ademiluyi and Oduola, 2011). Microwave popping and hot air popping are therefore the preferred methods for the health conscious, since they provide an option of popping without fat. This hybrid shows varying degree of resistant to major diseases in artificial condition in all the zone. It exhibited moderate resistant against MLB and charcoal rot in NWPZ (Table 5a). Moderate resistance against C. Rot, P. rust and TLB diseases in PZ (Table 5c). Same way this hybrid exhibited varying degree of resistance to stem borer Chillopartellus in natural condition. It exhibited moderate resistance against Chillopartellus in all three zone (Table 6).

In conclusion the high yielding, Popcorn hybrid IHPC-1203 is identified for Kharif cultivation in the NWPZ (North West Plain Zone-Punjab, Haryana, Delhi, Uttarakhand, Uttar Pradesh), NEPZ (North East Plain Zone-Bihar, Jharkhand, Odisha, Uttar Pradesh (Eastern region), West Bengal) and PZ (Peninsular zone-Maharashtra, Karnataka, Andhra Pradesh, Tamil Nadu). It produces pop corn yield of $3876 \mathrm{~kg} / \mathrm{ha}, 3294 \mathrm{~kg} / \mathrm{ha}$ and $49.22 \mathrm{~kg} / \mathrm{ha}$ in NWPZ, NEPZ and PZ, respectively. It is a medium maturing, orange flint grains and havinghigh popping (92\%) and popping volume $\left(213 \mathrm{ml} / \mathrm{cm}^{3}\right)$ and it is similar in grain colour and texture as of popular local cultivars. The produce of it will fetch high price from the market and popping industry. As looking to the biochemical parameters the produce of hybrid is of high quality, so it will fetch high price from the market also. So, after cultivation in the different states, it could improve the 
livelihood of the farmers. Popping volume, which is the most important quality character, was significantly higher in this hybrid than the check cultivars, Therefore, the hybrid cultivars should be grown instead of openpollinated cultivars under optimum environmental conditions, because quality is as important as yield in popcorn.

\section{Acknowledgement}

Director, Indian Institute of Maize Research (ICAR), Ludhiana.

\section{References}

Ademiluyi, F.T., and K. Oduola. (2011). Modelling the physical properties of popcorn varieties as a function of kernel moisture content. http://lejpt.academicdirect.org/A18/03 5_048.htm (accessed 8 November 2012).

Arnhold, E., F. Mora, R. G. Silva, P. I. V. Good-God, and M. A. Rodovalho, (2009). Evaluation of top-cross popcorn hybrids using mixed linear model methodology. Chilean J. of Agric. Res., 69 (69): 46-53.

Babic, M.; Pajic, Z. (1992): Effect of genotype $\times$ environment interaction on popping volume in popcorn hybrids (Zea mays L.). Genetika 1: 27-32.

CollinetPhumeleleJele February (2012). Genetic Analysis of Agronomic and Quality Traits in Popcorn Hybrids. Thesis submitted to University of KwaZulu-Natal Republic of South Africa. (original not seen).

Ceylan, M. and E. Karababa, (2004). The effects of ingredients on popcorn popping characteristics. Int. J. of Food Sci. and Tech. 39: 361-370.

Dofing, S. M.; Thomas-Compton, M. A.; Buck, J. S. (1990): Genotype X popping method interaction for popping volume in popcorn. Crop Science 30: 62-65.

Ertas, N., S. Soylu, and N. Bilgicli. (2009). Effects of kernel properties and popping methods on popcorn quality of different corn cultivars. J. of Food Process Engineering32: 478-496.

Gökmen, S. (2004). Effect of moisture content and popping method on popping characteristics of popcorn. $J$. of Food Engin. 65: 357-362.

Karababa, E. (2006). Physical properties of popcorn kernels. J. of Food Engineering 72: 100-107.

Mehmet Ali Sakin, SabriGokmen, Ahmet Yildirim, Savas Belen and Nejdet Kandemir (2005). Effects of cultivar type on yield and quality of popcorn (Zea mays (L.) everta), New Zealand Journal of Crop and Horticultural Science, 33:1, 17-23,

Pajic, Z. (1990).: Popcorn and sweet corn breeding. International Advanced Course Maize Breeding, Production, Processing and Marketing in Mediterranean Countries MAIZE'90. September 17 to October 13, 1990, Belgrade, Yugoslavia.

Park, D., and J.A. Maga.(2001). Color, texture and sensory evaluation of selected hybrids of popped popcorn. Journal of Food Quality 24: 563-574

Sakin, M. A., S. Gökmen, A. Yıldırım, S. Belen and N. Kandemir, (2005). Effects of cultivar type on yield and quality of popcorn (Zea mays everta). New Zealand J. of Crop and Horticultural Sci. 33:17-23

Soylu, S. and A. Tekkanat, (2007). Interactions amongst kernel properties and expansion volume in various popcorn genotypes. J. of Food Engin. 80; 336-341.

Singh, V., N.L. Barreiro, J. Mckinstry, P. Buriak, and S.R. Eckhoff. (2007). 
Effect of kernel size, location, and type of damage on popping characteristics of popcorn. Cereal Chemistry 74: 672-67 background, behavior, and breeding. in Hallauer, A. R. (Ed), Specialty Corns. 2. Edition, Florida, CRS Press. pp. 395-469.

Troyer, F., (2001). Temperate corn-

\section{How to cite this article:}

Patel, M. B., P. K. Parmar, K. H. Patel, S. K. Singh, H. S. Varma, V. J. Patel and Khanorkar, S. M. 2020. A New Single Cross Pop Corn Hybrid IHPC-1203 for Kharif Cultivation in North West Peninsular Zone, North East Peninsular Zone and Peninsular Zone. Int.J.Curr.Microbiol.App.Sci. 9(09): 1858-1866. doi: https://doi.org/10.20546/ijcmas.2020.909.234 